\title{
Fruit Morphology as Taxonomic Features in Five Varieties of Capsicum annuum L. Solanaceae
}

\author{
Daniel Andrawus Zhigila, ${ }^{1}$ Abdullahi Alanamu AbdulRahaman, \\ Opeyemi Saheed Kolawole, ${ }^{2}$ and Felix A. Oladele ${ }^{2}$ \\ ${ }^{1}$ Botany Programme, Department of Biological Sciences, Faculty of Science, Gombe State University, Gombe, Nigeria \\ ${ }^{2}$ Applied Plant Anatomy and Wood Technology Laboratory, Department of Plant Biology, University of Ilorin, Ilorin, Nigeria
}

Correspondence should be addressed to Daniel Andrawus Zhigila; dandrawus@ymail.com

Received 12 November 2013; Accepted 31 December 2013; Published 17 February 2014

Academic Editor: Peter J. de Lange

Copyright (C) 2014 Daniel Andrawus Zhigila et al. This is an open access article distributed under the Creative Commons Attribution License, which permits unrestricted use, distribution, and reproduction in any medium, provided the original work is properly cited.

\begin{abstract}
Variations in the fruit morphological features of Capsicum annuum varieties were studied. Varieties studied include var. abbreviatum, var. annuum, var. accuminatum, var. grossum, and var. glabriusculum. The fruit morphology revealed attenuated fruit shape with rounded surfaces in var. glabriusculum, and cordate fruit shape with flexuous surface in var. annuum, abbreviatum and accuminatum. The fruit is a berry and may be green, yellow, or red when ripe. The fruit epidermal cell-wall patterns are polygonal in shape with straight and curved anticlinal walls in all the five varieties. The fruit of var. abbreviatum and var. grossum is trilocular, while that of var. accuminatum and annuum is bilocular, and that of var. glabriusculum is tetralocular. Capsicum annuum var. glabriusculum had the highest mean number of seeds (108.4) and var. annuum had the lowest number of seeds (41.3) per fruit. The fruit is conspicuously hollowed in var. glabriusculum, accuminatum, and annuum but inconspicuously hollowed in var. abbreviatum and var. grossum. These features are shown to be good taxonomic characters for delimiting the five varieties of Capsicum annuum.
\end{abstract}

\section{Introduction}

Capsicum annuum $\mathrm{L}$. is a domesticated species of the plant genus Capsicum in the family Solanaceae [1], native to southern North America and northern South America [24]. The fruit is a berry and may be green, yellow, or red when ripe [5]. There are more than 200 common names in use for this species. The most common include chilli pepper, paprika (sweet varieties); bell pepper, cayenne, jalapeños, chiltepin (hot varieties); Christmas peppers (ornamental) $[4,6]$. In the past some woody forms of this species have been called C. frutescens, but the features that were used to distinguish those forms appear in many populations of C. annuum and there is no consistently recognizable $C$. frutescens species. [6]. Capsicum annuum can be difficult to separate from the cultivated $C$. chinense (the hottest pepper) and C. frutescens (tabasco pepper) and their morphological features can overlap. These three species share the same ancestral gene pool and are sometimes called the "annuumchinense-frutescens complex" [7]. Capsicum terminology is very confusing with pepper, chilli, chile, chili, aji, paprika, and capsicum all used interchangeably to describe the plant $[8,9]$. There are many local cultivars grown in West Africa. Nigeria alone has more than 200 selections of pepper [10].

Sweet peppers are very often used as a bulking agent in ready-made meals and take-away food, because they are cheap, have a strong flavour, and are colourful (Janick \& Paull, 2009); [11]. Its potential uses and benefits to mankind cover many areas such as food and nutrition, medicine, cosmetics, plant based insecticides (PBI), and income [12]. The colourful aspect of peppers increases the visual appeal of the food, making it more appetizing. Foods containing peppers, especially chili peppers, often have a strong aftertaste which is due to the presence of capsinoids in peppers [13]. 


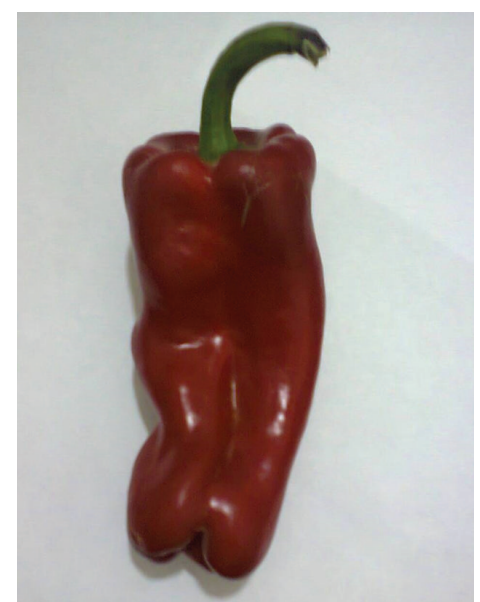

Figure 1: Side view of the fruit of Capsicum annuum var. glabriusculum.

The fruits of nonpungent (sweet) varieties are eaten raw in salads or cooked as a vegetable [14]. They are rich sources of vitamin $\mathrm{C}$ (ascorbic acid) and vitamin A. The dried fruits are ground to a powder (paprika) and used as an ingredient in curry powder [8].

The varieties and cultivars of Capsicum annuum are classified on the basis of their fruit shapes. Fruits form as the result of the development and differentiation of the gynoecium after fertilization. They are therefore the product of late morphological and structural modifications in the carpels $[15,16]$. The genus Capsicum (sweet and hot pepper) shows intra- and inter-specific diversity in fruit type, colour, shape, taste, and biochemical content [12]. The species encompass a wide variety of shapes and sizes of peppers, both mild and hot, ranging from bell peppers to chili peppers [6]. There has been much debate amongst botanists and taxonomists as to number and classification of Capsicum species; but it is now widely accepted that the genus Capsicum consists of five domesticated species and twenty-six wild species [7]. Fruit characters have been extensively used in the taxonomy of the family Solanaceae [17]. Excellent reviews of the application of morphological and anatomical features in systematic studies are shown in the works of Okwulehi and Okoli [18], Chakrabarty and Gupta [19], Olowokudejo [20], and Nwachukwu et al. [21].

The present study assessed fruit morphological features in five varieties of $C$. annuum in order to evaluate the reliability of these characters and their relevance to the taxonomic consideration of the C. annuum varieties studied.

\section{Materials and Methods}

Living fresh materials were used in this study. The fruits of Capsicum annum varieties were obtained from plant stands and Ipata markets in Ilorin, Kwara State, Nigeria. Photographs of all the specimens collected were taken with digital camera during the field trips. The specimens were identified at the herbarium of the Department of Plant

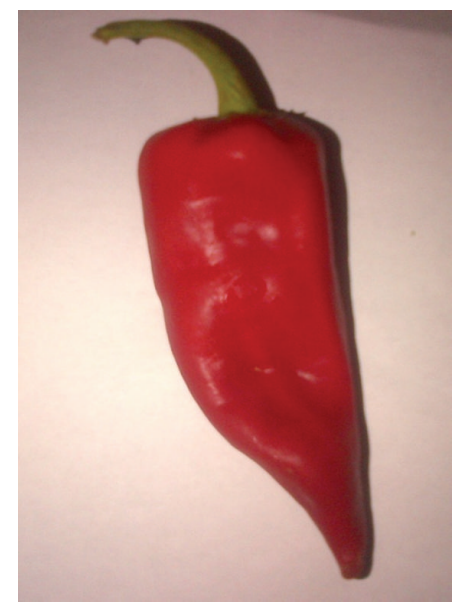

Figure 2: Side view of the fruit of Capsicum annuum var. grossum.

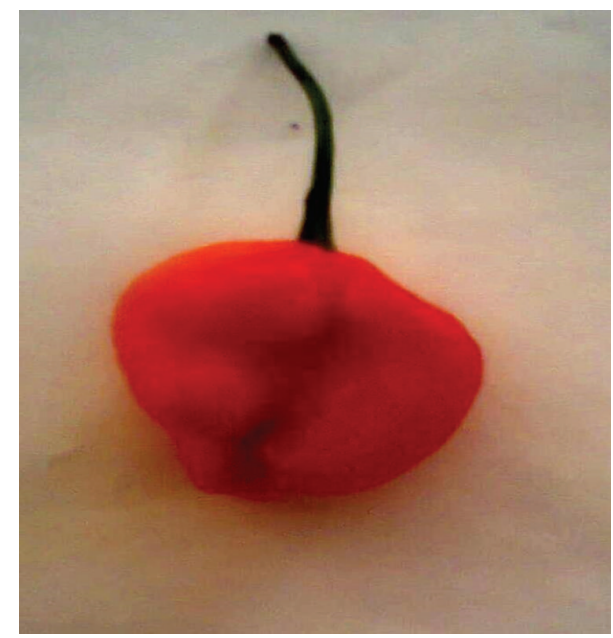

FIGURE 3: Side view of the fruit of Capsicum annuum var. abbreviatum.

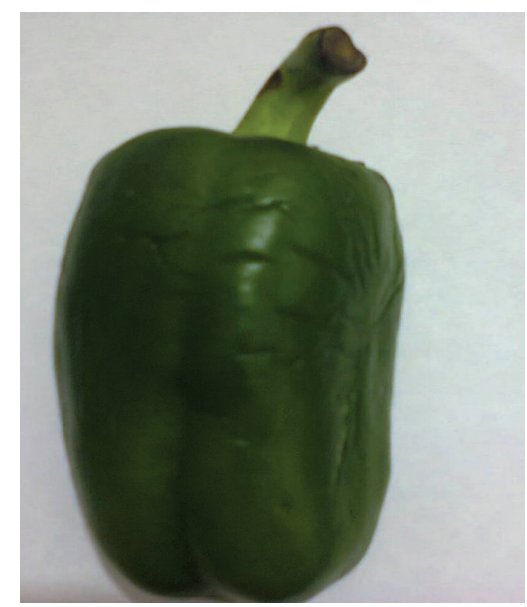

Figure 4: Side view of the fruit of Capsicum annuum var. accuminatum. 
TABLE 1: Fruits morphological parameters in the varieties of Capsicum annuum.

\begin{tabular}{|c|c|c|c|c|c|c|}
\hline Taxa & $\begin{array}{c}\text { Fruit length } \\
(\mathrm{mm})\end{array}$ & $\begin{array}{l}\text { Fruit breadth } \\
(\mathrm{mm})\end{array}$ & $\begin{array}{l}\text { Fruit stalk length } \\
\qquad(\mathrm{mm})\end{array}$ & Fruit shape & Fruit surface & Fruit colour \\
\hline $\begin{array}{l}\text { C. annuum var. } \\
\text { abbreviatum }\end{array}$ & $42.35 \pm 3.15$ & $35.57 \pm 4.12$ & $27.94 \pm 3.46$ & Cordate & Flexuous & Red or yellow \\
\hline $\begin{array}{l}\text { C. annuum var. } \\
\text { annuum }\end{array}$ & $70.98 \pm 1.08^{\mathrm{a}}$ & $19.85 \pm 0.54^{\mathrm{a}}$ & $36.59 \pm 1.68^{\mathrm{a}}$ & Cordate & Flexuous & Green or red \\
\hline $\begin{array}{l}\text { C. annuum var. } \\
\text { accuminatum }\end{array}$ & $71.36 \pm 1.75^{\mathrm{a}}$ & $45.37 \pm 0.91$ & $36.58 \pm 1.69^{\mathrm{a}}$ & Cordate & Flexuous & Green \\
\hline $\begin{array}{l}\text { C. annuum var. } \\
\text { grossum }\end{array}$ & $114.10 \pm 1.58$ & $65.32 \pm 4.05$ & $43.78 \pm 1.12^{\mathrm{ab}}$ & Attenuate & Rounded & Red \\
\hline $\begin{array}{l}\text { C. annuum var. } \\
\text { glabriusculum }\end{array}$ & $126.69 \pm 4.05$ & $19.51 \pm 2.05^{\mathrm{a}}$ & $44.94 \pm 3.68$ & Cordate & Rounded & Red \\
\hline
\end{tabular}

Means with similar indices in each column are not significantly different $(P \leq 0.05)$.

TABLE 2: Fruits epidermal characters in the varieties of Capsicum annuum.

\begin{tabular}{|c|c|c|c|c|c|}
\hline \multirow[b]{2}{*}{ Taxa } & \multicolumn{5}{|c|}{ Epidermal cell characteristics } \\
\hline & $\begin{array}{l}\text { Length } \\
(\mu \mathrm{m})\end{array}$ & $\begin{array}{l}\text { Breadth } \\
(\mu \mathrm{m})\end{array}$ & $\begin{array}{l}\text { Size } \\
(\mu \mathrm{m})\end{array}$ & Shape & Anticlinal wall \\
\hline $\begin{array}{l}\text { C. annuum var. } \\
\text { abbreviatum }\end{array}$ & $15(23.00) 31$ & $13(18.08) 25$ & 328.51 & Polygonal & Straight, curve \\
\hline $\begin{array}{l}\text { C. annuum var. } \\
\text { Аnпuиm }\end{array}$ & $11(20.00) 30$ & $10(14.92) 20$ & 235.74 & Polygonal & Straight, curve \\
\hline $\begin{array}{l}\text { C. annuum var. } \\
\text { accuminatum }\end{array}$ & $13(18.42) 24$ & $10(14.58) 21$ & 212.17 & Polygonal & Straight, curve \\
\hline $\begin{array}{l}\text { C. annuum var. } \\
\text { Grossum }\end{array}$ & $38(41.90) 45$ & $13(16.75) 21$ & 554.44 & Polygonal & Straight, curve \\
\hline $\begin{array}{l}\text { C. annuum var. } \\
\text { glabriusculum }\end{array}$ & 18 (21.67) 30 & $15(16.50) 28$ & 282.47 & Polygonal & Straight, curve \\
\hline
\end{tabular}

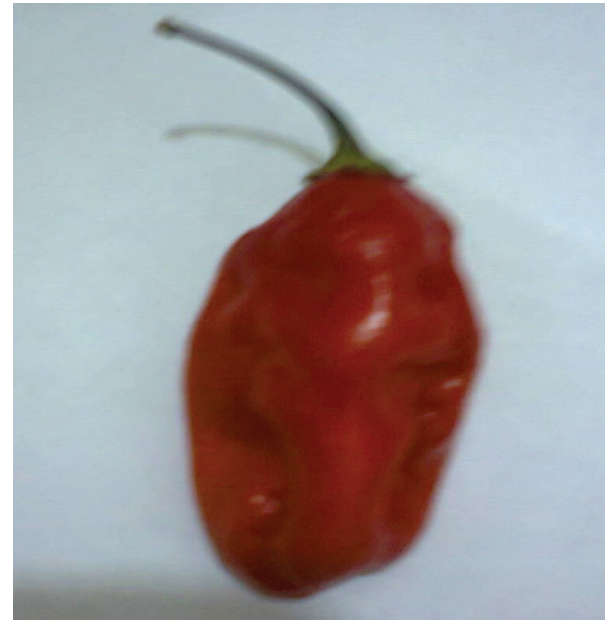

Figure 5: Side view of the fruit of Capsicum annuum var. annuum.

Biology, University of Ilorin, Ilorin, Kwara State, and authenticated at the National Center for Genetic Resources and Biotechnology, Ibadan, Oyo State, Nigeria.

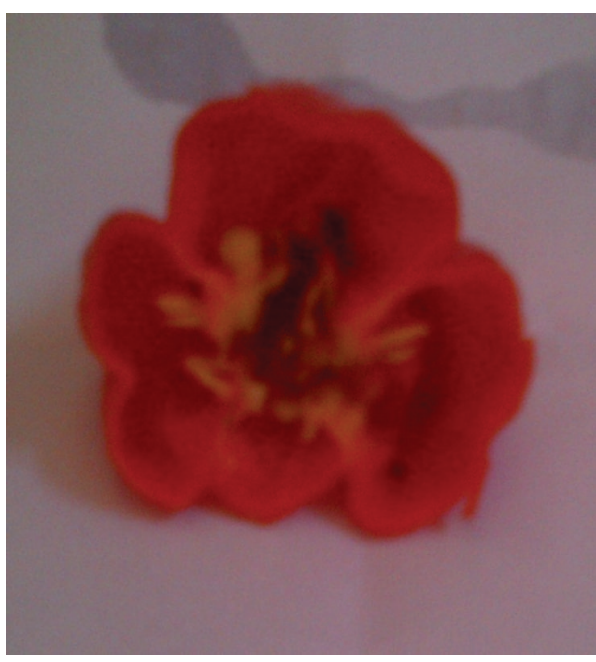

FIgURE 6: Transverse section of the fruit of var. annuum showing it inconspicuously hollowed.

Both qualitative and quantitative characters of fruits were used. The fruits were carefully observed for qualitative characters such as fruit type, shape, apex, surface, base, 
TABLE 3: Characteristics of the fruit interior in Capsicum annuum varieties.

\begin{tabular}{|c|c|c|c|c|}
\hline \multirow{2}{*}{ Taxa } & \multicolumn{4}{|c|}{ Characteristics of the fruits interior } \\
\hline & Locule & Placentation & Number of Seeds & Hollow \\
\hline $\begin{array}{l}\text { C. annuum var. } \\
\text { abbreviatum }\end{array}$ & trilocular & Axile & $43(60.4) 81$ & less hollowed \\
\hline $\begin{array}{l}\text { C. annuum var. } \\
\text { Anпuит }\end{array}$ & bilocular & Axile & $39(41.3) 44$ & hollowed \\
\hline $\begin{array}{l}\text { C. annuum var. } \\
\text { accuminatum }\end{array}$ & bilocular & Axile & $58(73.8) 88$ & hollowed \\
\hline $\begin{array}{l}\text { C. annuum var. } \\
\text { Grossum }\end{array}$ & trilocular & Axile & $61(68.5) 70$ & less hollowed \\
\hline $\begin{array}{l}\text { C. annuum var. } \\
\text { glabriusculum }\end{array}$ & tetralocular & Axile & $97(108.4) 122$ & hollowed \\
\hline
\end{tabular}

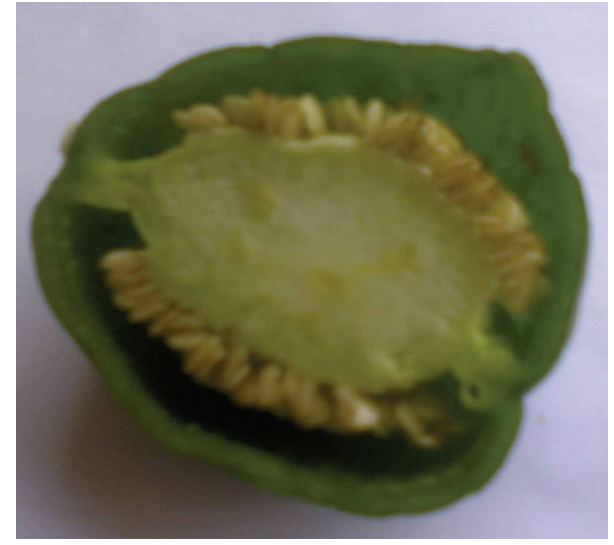

FIGURE 7: Fruit of var. accuminatum showing two fused carpels with axile placentation (bilocular).

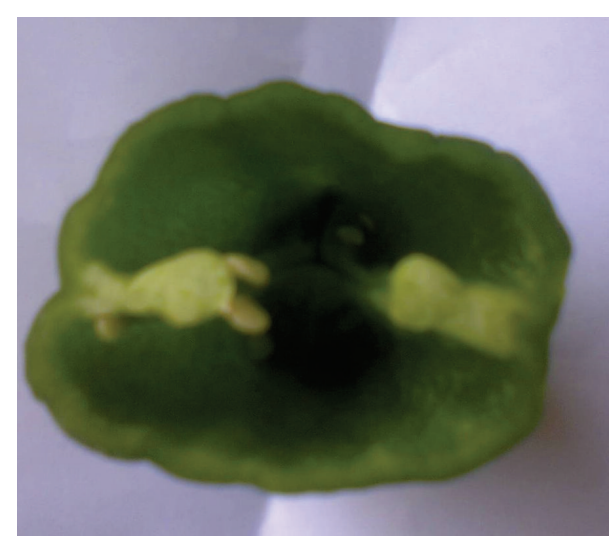

FIGURE 8: Transverse section of the fruit var. accuminatum showing it conspicuously hollowed.

and colour and quantitative features such as fruit length, width, stalk length, and fruit index measured and recorded using standardized electronic digital callipers. The fruits were observed, measured, and recorded using 30 randomly selected fruits as suggested by Radford et al., [22]. And the

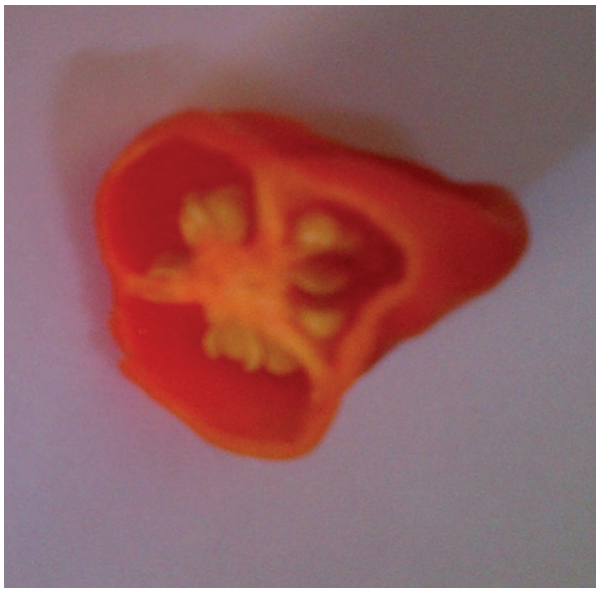

Figure 9: Fruit of three fused carpels with axile placentation (trilocular).

ranges of variations of these characters were also noted. Terminologies used throughout were those of Pandey and Misra [23] and Olorode [24].

All data were processed using Analysis of Variance (ANOVA) and Duncan Multiple Range Test (DMRT). Computer software used was SPSS version 17. A probability value of 0.05 was used as a bench mark for significant difference between parameters.

\section{Results and Discussion}

The fruit length is one of the important characteristics, which help in differentiating the varieties as small, medium, and large. The Capsicum varieties exhibited significant variability in fruit length ranging from $42.35 \mathrm{~mm}$ (var. abbreviatum) to $126.69 \mathrm{~mm}$ (var. glabriusculum). Based on this variation in fruit length, the five varieties under study were grouped into small $(<50 \mathrm{~mm})$ as recorded by var. abbreviatum, medium (51-100 $\mathrm{mm})$ as recorded by var. annuum and accuminatum, and large (>101 mm) as recorded by var. grossum and glabriusculum. Similar classification was reported by Surendra and Singhal [25] in peas, Ravi [26] in soybean, Jain et al. [27] in 


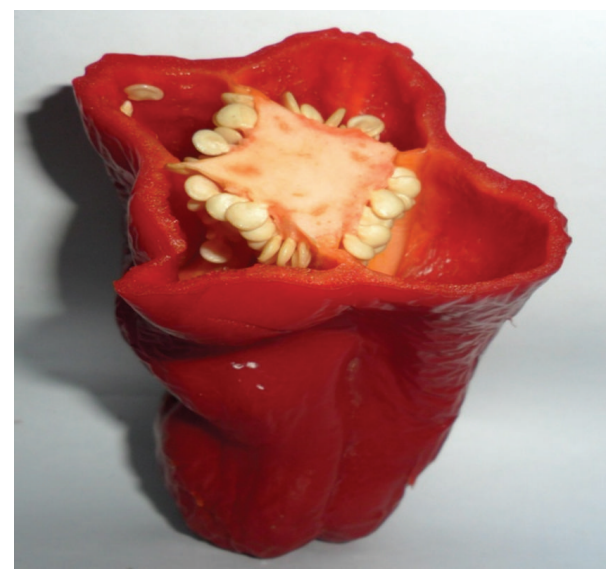

FIGURE 10: Fruit of four fused carpels with axile placentation (tetralocular).

mung bean, and Mate and Shelar [28] in sorghum varieties. The wide variation in fruit length might be due to variation in genetic constitution of the varieties as the fruit length is controlled by three to ten pairs of genes with heritability value of 40 to 50 per cent in Capsicum [29]. The fruit length might have also been influenced by agronomic and environmental conditions. Moreover, Duncan Multiple Range Test (DMRT) - one-way ANOVA-revealed the fruit length of C. annuum var. accuminatum and var. annuum to be not significantly different, while the fruit breadths of C. annuum var. glabriusculum and var. annuum are also not significantly different (Table 1). The fruit shape of C. annuum var. grossum was attenuated, that is, pointed toward the apex with rounded surfaces, while C. annuum var. annuum, var. accuminatum, var. glabriusculum, and var. abbreviatum are cordate or truncated and have flexuous (wavy) surfaces (Table 2 and Figures 1, 2, 3, 4, and 5). This difference in the shape and surface of variety glabriusculum as suggested by Singh [30] is the most likely progenitor of the domesticated C. annuum var. annuum. Serebryanaya and Shipunov [31] reported that changes in plant morphological features in terms of variation have been attributed to small-scale evolutionary processes in different varieties of plants. The variability in fruits colour may be used to establish phylogenetic relationship among the varieties. Colour has been a major basis of differentiating Capsicum annuum varieties. The green colour in var. accuminatum does not change even in mature fruits (Abdul, pers. comm.).

A wide range of variability in morphology was observed in the transverse sections of these varieties (Table 3 and Figures 6-10). The fruit of var. abbreviatum and var. grossum is trilocular (Figure 9), var. accuminatum and var. annuum is bilocular (Figure 7), and var. glabriusculum is tetralocular (Figure 10). This heterogeneity in the ovary chambers suggests phylogenetic diversity among these varieties. The axile placentation in all the varieties indicates that the carpel sides are fused together in septa and the ovary in Capsicum annuum is plurilocular. There are diagnostic features in the number of seeds per fruit in the varieties of Capsicum annuum. Var. grossum recorded the highest mean number of seeds (108.4) and var. annuum recorded the lowest number of seeds (41.3) per fruit. The fruit is conspicuously hollowed (Figure 8) in var. grossum, accuminatum, and annuum but inconspicuously hollowed in var. abbreviatum and var. glabriusculum (Figure 6). These variations in the fruit internal structure are probably due to the length and/or size of the fruits.

These distinguishing fruit morphological features observed in these investigations are of systematic value because they are consistently different in the taxa studied. Furthermore, the use of fruit features in systematics is an important taxonomic tool at the levels of family, genus, species, and variety. Works of Mulla et al. [32], Filippa and Bernardello [33], Olmstead et al. [34], Cutler et al. [15], and Pabón-Mora and Litt [17] are typical examples.

Based on the features observed above, the following dichotomous key has been developed to allow for separation of the five varieties of Capsicum annuum studied in this work:

(1a) fruit shape cordate, fruit internal structure, conspicuously hollowed,-2

(2a) fruit surface flexuous, fruit small or medium,-3

(3a) fruit colour red or yellow, fruit small, trilocular,-abbreviatum

(3b) fruit colour green or red, fruit medium, bilocular,-annuum

(2b) fruit surface rounded, fruit large,-grossum

(1b) fruit shape attenuate, fruit internal structure inconspicuously hollowed,-4

(4a) fruit colour green, number of seeds low,accuminatum

(4b) fruit colour red, number of seeds high,glabriusculum

\section{Conflict of Interests}

The authors declare that there is no conflict of interests regarding the publication of this paper.

\section{References}

[1] W. H. Greenleaf, "Pepper breeding," in Breeding Vegetable Crops, M. J. Basset, Ed., pp. 67-134, The AVI Publishing Company, Westport, Conn, USA, 1986.

[2] G. J. H. Grubben and I. M. El Tahir, "Capsicum annuum L.," in PROTA 2: Vegetables/Légumes, G. J. H. Grubben and O. A. Denton, Eds., PROTA Foundation, Wageningen, The Netherlands, 2004.

[3] GRIN, Germplasm Resources Information Network. United States Department of Agriculture. 1997-01-22, 2010, http://www. ars-grin.gov/cgi-bin/npgs/html/taxon.pl?8904.

[4] E. Latham, “The colourful world of chillies. Stuff.co.nz”, 2009, http://www.stuff.co.nz/life-style/food-wine/1756288.

[5] Organisation for Economic Co-operation and Development, Safety Assessment of Transgenic Organisms: OECD Consensus Documents, OECD Publishing, 2006. 
[6] Z. Zhang, A. Lu, and W. G. D’arcy, "Capsicum annuum Linnaeus, Special Plant 1:188.1753," Flora of China, vol. 17, pp. 313313, 2002.

[7] A.-M. Araceli, P. L. Morrell, M. L. Roose, and S.-C. Kim, "Genetic diversity and structure in semiwild and domesticated chiles (Capsicum annuum ; Solanaceae) from Mexico," American Journal of Botany, vol. 96, no. 6, pp. 1190-1202, 2009.

[8] D. DeWitt and P. W. Bosland, Complete Chile Pepper Book: A Gardener's Guide to Choosing, Growing, Preserving, and Cooking, Timber Press, 2009.

[9] M. Mcmullan and J. Livsey, "The chileman. BOLVIAN GOLD (PI, 260579): baccatum," Bolivia, Brazil, 2013.

[10] O. O. Idowu-Agida, D. J. Ogunniyan, and E. O. Ajayi, "Flowering and fruiting behavior of long cayenne pepper (Capsicum frutescens L.)," International Journal of Plant Breeding and Genetics, vol. 6, no. 4, pp. 228-237, 2012.

[11] Organisation for Economic Co-operation and Development, Safety Assessment of Transgenic Organisms: OECD Consensus Documents, OECD Publishing, 2011.

[12] S. Dagnoko, N. Yaro-Diarisso, P. N. Sanogo et al., "Overview of Pepper (Capsicum spp.) breeding in West Africa," African Journal of Agricultural Research, vol. 8, no. 13, pp. 1108-1114, 2013.

[13] G. J. H. Grubben and O. A. Denton, Plant Resources of Tropical Africa 2. Vegetables, PROTA Foundation, Wageningen, The Netherlands, 2004.

[14] J. Janick and R. E. Paull, The Encyclopaedia of Fruit \& Nuts, CAB International, Wallingford, UK, 2008.

[15] D. F. Cutler, C. E. J. Botha, and D. W. Stevenson, Anatomy: An Applied Approach, Blackwell, Malden, Mass, USA, 2008.

[16] L. Roth, Fruits of Angiosperms, Gebrüder Borntraeger, Berlin, Germany, 1977.

[17] N. Pabón-Mora and A. Litt, "Comparative anatomical and developmental analysis of dry and fleshy fruits of Solanaceae," American Journal of Botany, vol. 98, no. 9, pp. 1415-1436, 2011.

[18] I. C. Okwulehi and B. E. Okoli, "Morphological and palynological studies in some species of Corchorus L. Tiliaceae," New Botanist, vol. 25, pp. 87-102, 1999.

[19] T. Chakrabarty and D. Gupta, "Morpho-histologic studies on three herbaceous species of railway track," Proceedings: Plant Sciences, vol. 90, no. 4, pp. 305-312, 1981.

[20] J. D. Olowokudejo, "Comparative morphology of leaf epidermis in the genus Annona (Annonaceae) in West Africa," Phytomorphol, vol. 40, pp. 407-422, 1990.

[21] C. U. Nwachukwu, F. N. Mbagwu, and A. N. Onyeji, "Morphological and leaf epidermal features of Capsicum annuum and Capsicum frutescens Solanaceae," Nature and Science, vol. 5, no. 3, pp. 54-60, 2007.

[22] A. E. Radford, W. C. Dickson, J. R. Massey, and C. R. Bell, Vascular Plant Systematics, Harper and Row, New York, NY, USA, 1976.

[23] S. N. Pandey and S. P. Misra, Taxonomy of Angiosperms, Ane Books Pvt, New Delhi, India, 2009.

[24] O. Olorode, Taxonomy of West African Flowering Plants, Longman Group Limited, Ile-Ife, Nigeria, 1984, The Book Project, Obafemi Awolowo University.

[25] P. Surendra and N. C. Singhal, "Characterization of some Indian pea (Pisum sativum L.) cultivars," Seed Research, vol. 25, no. 1, pp. 53-58, 1997.
[26] Ravi, Identification of soybean varieties based on seed, seedling and plant characters [M.S. thesis], University of Agricultural Sciences, Bangalore, India, 1999.

[27] S. K. Jain, D. Khare, M. S. Bhale, and N. D. Raut, "Characterization of mung bean varieties for verification of genetic purity," Seed Tech News, vol. 32, no. 1, pp. 200-201, 2002.

[28] S. N. Mate and V. R. Shelar, "Morphological characterization of sorghum hybrids and their parental lines," in Proceedings of the 12th Abstract National Seed Seminar, pp. 175-176, Angrau, Hyderabad, India, February 2006.

[29] E. A. Weiss, Castor, Sesame and Safflower, Leonard Hill Books, London, UK, 1971.

[30] R. J. Singh, Genetic Resources, Chromosome Engineering, and Crop Improvement: Vegetable Crops, CRC Press, 2006.

[31] A. Serebryanaya and A. Shipunov, "Morphological variation of plants on the uprising islands of northern Russia," Annals of Botany, Fennici, vol. 46, no. 2, pp. 81-89, 2009.

[32] R. M. Mulla, Y. Dave, and B. A. Kazi, "Structure and development of the pericarps of Cestrum diurnum and Cestrum nocturnum," Phytomorphology, vol. 55, no. 3-4, pp. 203-210, 2005.

[33] E. M. Filippa and L. M. Bernardello, "Estructura y desarrollo de fruto y semilla en especies de Athenaea, aureliana y capsicum (Solaneae, Solanaceae)," Darwiniana, vol. 31, pp. 137-150, 1992.

[34] R. G. Olmstead, L. Bohs, H. A. Migid, E. Santiago-Valentin, V. F. Garcia, and S. M. Collier, "A molecular phylogeny of the Solanaceae," Taxon, vol. 57, no. 4, pp. 1159-1181, 2008. 

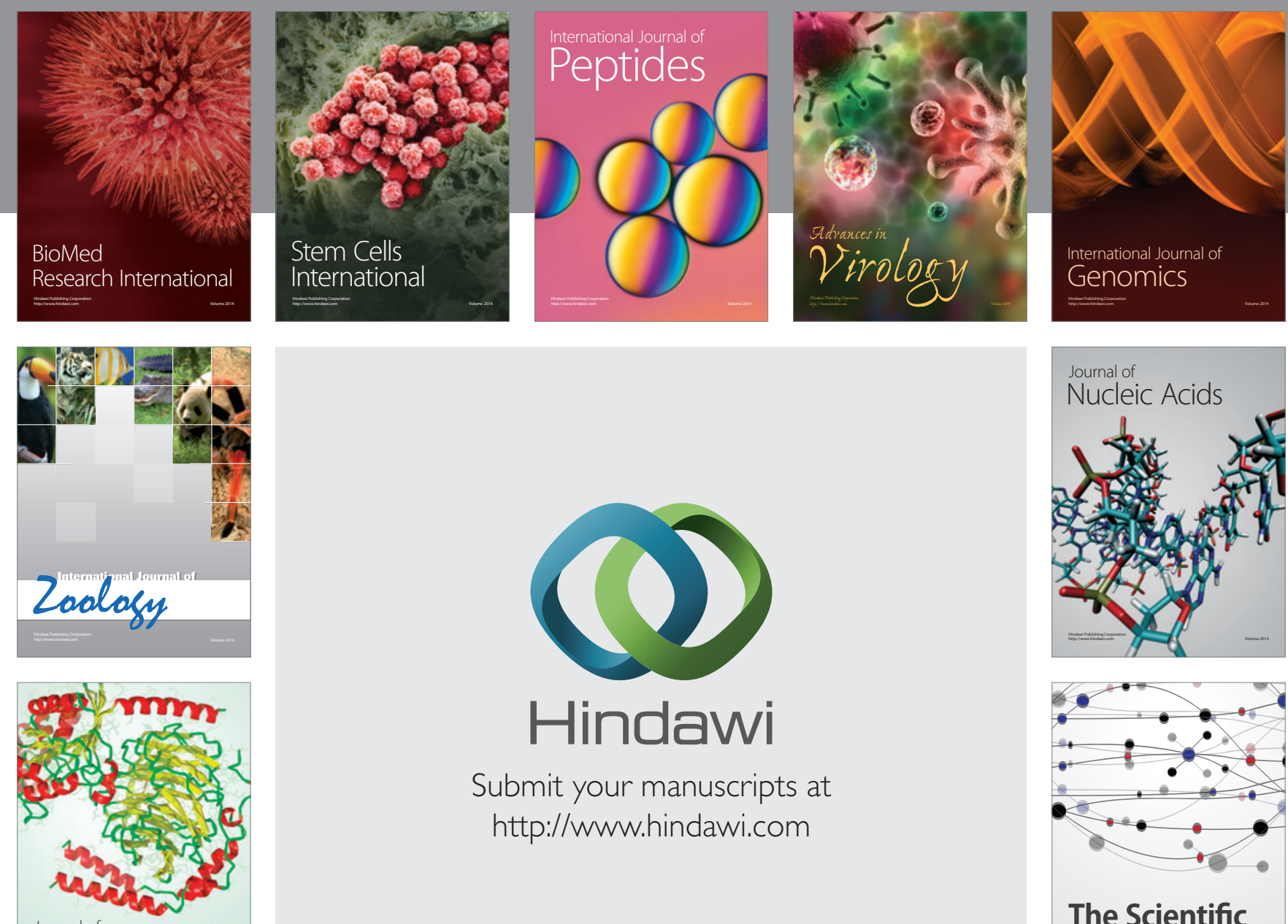

Submit your manuscripts at

http://www.hindawi.com

Journal of
Signal Transduction
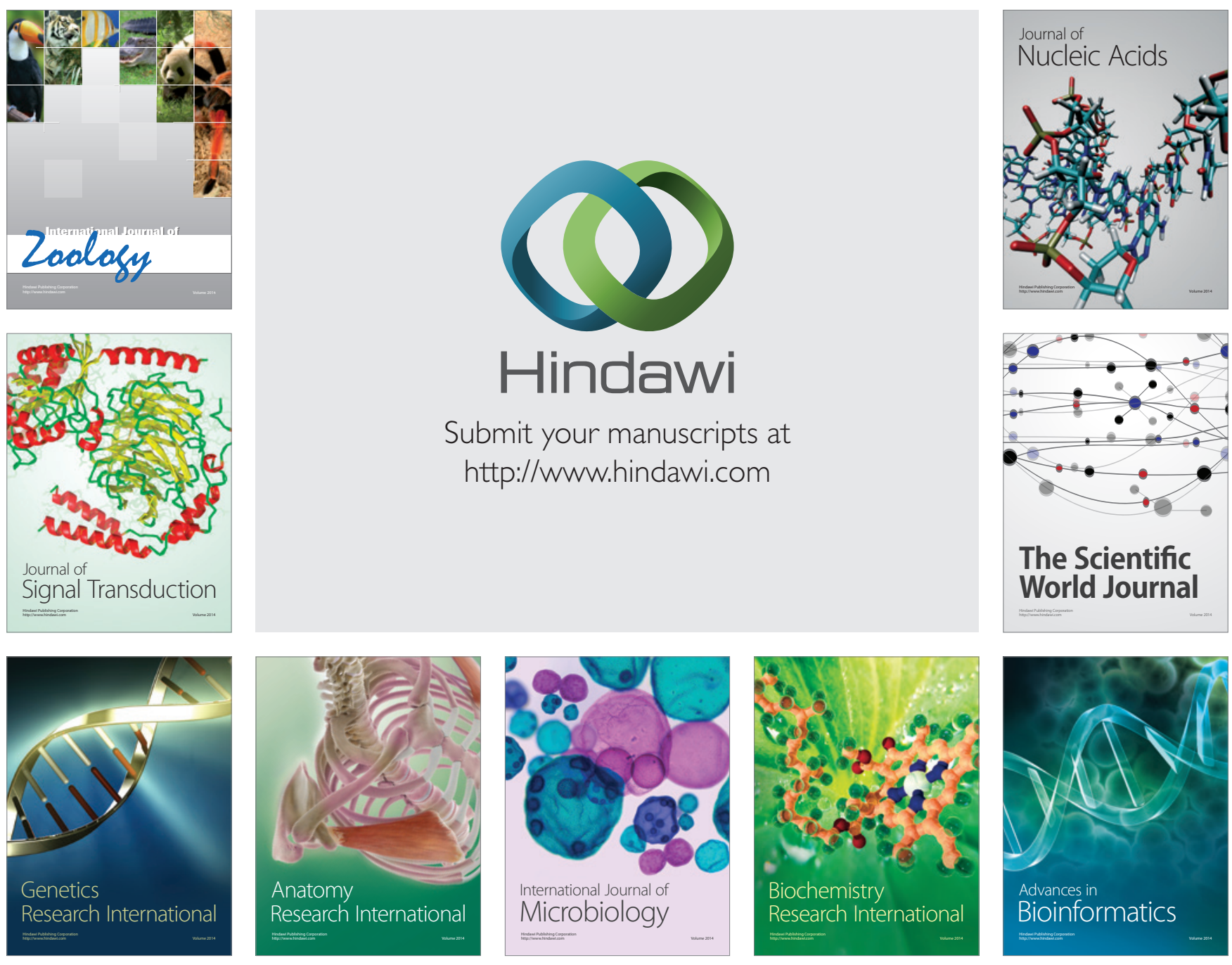

The Scientific World Journal
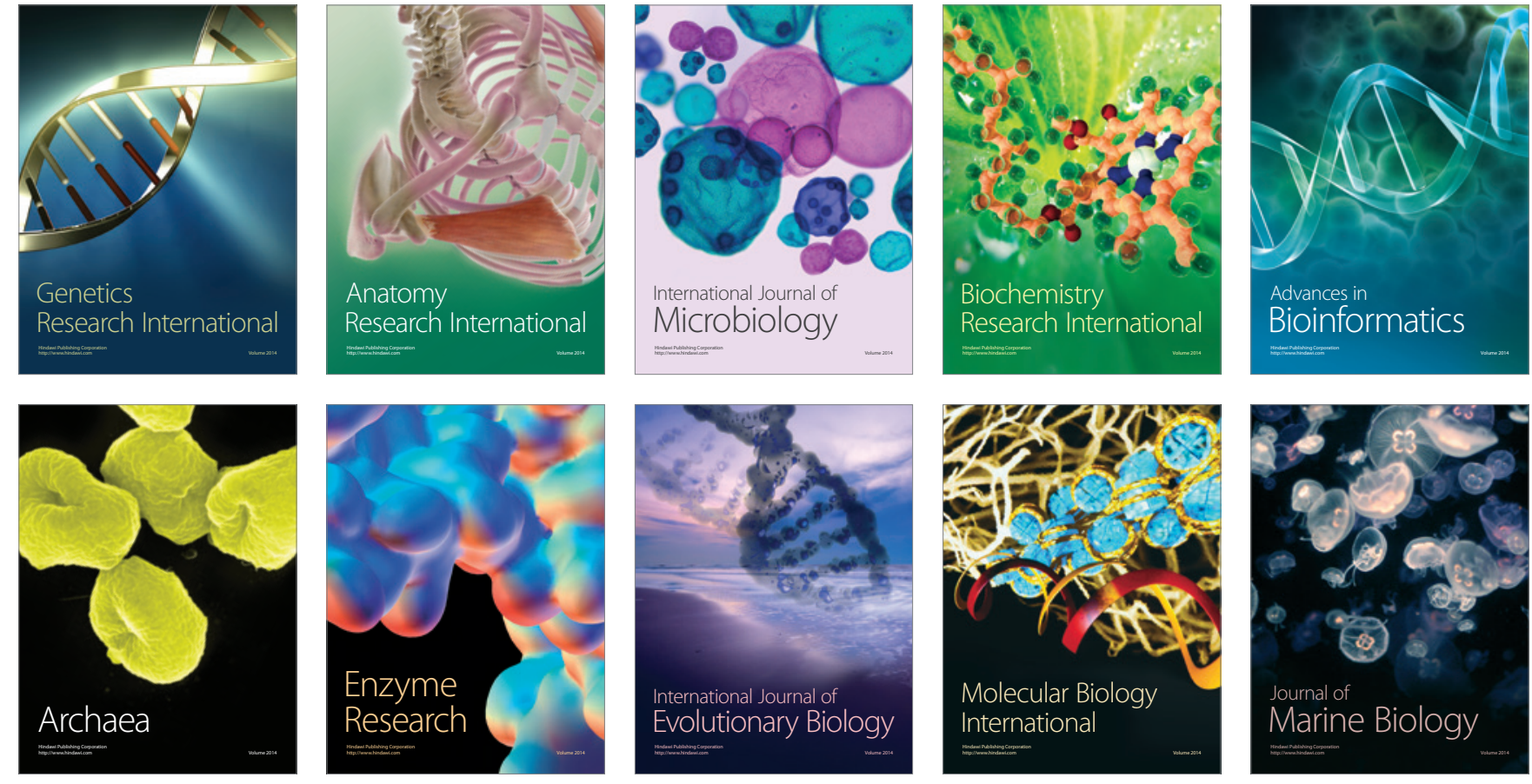